\title{
Sitobion graminis Takahashi, 1950 (Hemiptera, Aphididae) - first record in Brazil, biological and morphometric parameters ${ }^{1}$
}

\author{
Josiane Teresinha Cardoso²; Sonia Maria Noemberg Lazzari² \& Regina Célia Zonta de Carvalho ${ }^{3}$
}

\author{
${ }^{1}$ Contribuição $n^{\circ} 1573$ do Departamento de Zoologia, Universidade Federal do Paraná \\ ${ }^{2}$ Depto. de Zoologia / Universidade Federal do Paraná, UFPR. Caixa Postal 19020, CEP 81531-980 Curitiba-PR. jositc@yahoo.com.br; \\ lazzari@ufpr.br \\ ${ }^{3}$ Centro de Diagnóstico Marcos Enrietti / SEAB, CDME/SEAB - PR. Rua Jaime Balão 575, CEP 80340-040 Curitiba-PR.
}

\begin{abstract}
Sitobion graminis Takahashi, 1950 (Hemiptera, Aphididae) - first record in Brazil, biological and morphometric parameters. The species Sitobion graminis Takahashi, 1950 (Hemiptera, Aphididae) was first detected in Brazil in 1998, in Curitiba, Paraná state, associated with the grass species Erianthus sp., Calamagrotis sp. and Paspalum urvilei. Both the field-collected and laboratory-reared specimens presented a noticeable intrapopulational variation in body and appendix length and in dorso-abdominal sclerotization. This species has been recorded in Malaysia, New Guinea, India, Philippines and Africa, where it colonizes several species of Poaceae. S. graminis differs from other Sitobion species from Brazil associated with grasses, as it presents black cauda and siphunculi and exhibits a constriction in the base of the last rostral segment. Biological data were obtained in the laboratory by rearing newborn nymphs on the inflorescence of the host plants. They passed through four nymphal instars. The mean duration of the nymphal stage was of 11.4 days, with a mortality ratio of $36.5 \%$. The mean pre-larviposition period was of 1.8 days; mean longevity of the females was 25.2 days; and mean fecundity was 18.7 nymphs/female, ranging from 2 to 41 nymphs/female.
\end{abstract}

KEYWORDS. Biological aspects; grass aphids; morphometrics.

RESUMO. Sitobion graminis Takahashi, 1950 (Hemiptera, Aphididae) - primeiro registro para o Brasil, parâmetros biológicos e morfométricos. A espécie Sitobion graminis Takahashi, 1950 (Hemiptera, Aphididae) foi detectada no Brasil pela primeira vez em 1998, em Curitiba, PR, associada às gramíneas Erianthus sp., Calamagrotis sp. e Paspalum urvilei. Os espécimes coletados e criados apresentavam uma notável variação intrapopulacional no comprimento do corpo e apêndices e na esclerotinização dorso-abdominal. Esta espécie é reconhecida na Malásia, Nova Guiné, Índia, Filipinas e África, colonizando várias espécies de Poaceae. S. graminis diferencia-se das demais espécies do gênero Sitobion associadas a gramíneas no Brasil, por apresentar a cauda e sifúnculos negros e o último segmento rostral constrito na base. Dados de biologia foram obtidos em laboratório, onde ninfas recém-nascidas criadas sobre as inflorescências das gramíneas hospedeiras, desenvolveram-se em quatro instares. A duração média do estágio ninfal foi de 11,4 dias, com mortalidade de $36,5 \%$. O período médio de pré-larviposição foi de 1,8 dias; longevidade média das fêmeas de 25,2 dias; fecundidade média de 18,7 ninfas/fêmea, variando de 2 a 41 ninfas/fêmea.

PALAVRAS-CHAVE. Aspectos biológicos; morfometria; pulgão de gramíneas.

The genus Sitobion Mordviko, 1914 (Hemiptera, Aphididae, Macrosiphini) consists of about 100 species associated with pteridophytes, monocotyledons and dicotyledons. In the American continent 14 species are known (Blackman \& Eastop 1984), while in Brazil six species have been recorded so far: Sitobion avenae (Fabricius, 1775), Sitobion lambersi David, 1956 and Sitobion pauliani Remaudière, 1957 associated with Poaceae; Sitobion luteum (Buckton, 1876) associated with Orchidaceae; Sitobion ptericolens (Patch, 1919) with the Pteridophyta and Asteraceae and Sitobion salviae (Bartholomew, 1932) with Laminaceae and Solanaceae (Costa et al. 1993; Voegtlin et al. 2003).

The grain aphid, $S$. avenae, is one of the most economically important species of Sitobion throughout the world. In Brazil, it attacks wheat, oat and barley crops and is a vector of the barley yellow dwarf virus. The species Sitobion graminis Takahashi, 1950 is also associated with gramineae and it was first described by Takahashi (1950) as a subspecies of $S$. avenae because they are morphologically similar. Eastop (1955) described the species as Macrosiphum (Sitobion) gathaka (Eastop, 1955) making a detailed description of the aptera and winged morphs. Initially recorded in Malaysia, the species has been found in New Guinea, India, Philippines, Angola, Kenya, Burundi, Madagascar, Cameroon and South Africa, but there is no reference to the presence of this species on the American continent (Takahashi 1950; Eastop 1955; Remaudière \& Autrique 1985; Blackman \& Eastop 1984).

Sitobion graminis can infest several gramineae species, including wheat and oats, although there is no reference to its possible damage to those host plants. In Africa, S.graminis is associated with grasses of the genera: Andropogon; Bouteloua; Brachiaria; Bromus; Chloris; Chrysopogon; Cynodon; Digitaria; Eleusine; Eragrostis; Exotheca; Festuca; Hyparrhenia; Melinis; Miscanthus; Oryza; Paspalum; Perotis; Poa; Rhynchelytrum; Setaria; Sporobolus; Themeda; Triticale; Triticum; and Zea (Remaudière et al. 1985). In Burundi, the species also attacks several grass species and occurs mainly from May to December, 
becoming very important at the end of the rainy season (Remaudière \& Autrique 1985).

In Kenya, there are several species of parasitoids of $S$. graminis, but in Burundi no parasitoid has been detected on this aphid species (Eastop 1955; Remaudière \& Autrique 1985).

The main objectives of this research were to record the first occurrence of $S$. graminis in Brazil and its association with host plants and to provide a comprehensive morphological and biological diagnosis of the species.

\section{MATERIAL AND METHODS}

The species was collected with yellow pan traps placed on supports $1 \mathrm{~m}$ above the soil, in 1997 and 1998, on the Centro Politécnico campus of the Universidade Federal do Paraná, in Curitiba. After the detection of the species in the traps, it was sought on possible host plants from the area.

The evaluation of the biological parameters was carried out in the Department of Zoology of the Universidade Federal do Paraná. A total of 30 newborn nymphs from eight field females were individualized on stems of one of its host plants, Paspalum urvilei: a single nymph on each stem. Each stem was placed on a Petri dish lined with moistened filter paper. They were observed daily, and records were kept of the duration and mortality of each nymphal instar as well as the longevity and fecundity of adult females.

The adults from the first and second generations were fixed in $70 \%$ ethanol and mounted on permanent slides, according to Martin's technique (1983). The measurements were taken under stereomicroscope.

Fifteen morphological characteristics of 77 apterous and seven alate parthenogenetic females were measured: body length, hind tibia, hind femur, siphunculus length, reticulation on the siphunculus, caudal length, antennal segments III, IV and $\mathrm{V}$, base of antennal segment VI and processus terminalis, ultimate rostral segment, hind tarsus segment II and longest hairs of antennal segment II and cephalic hair. The number of caudal hairs and the number of rhinaria were counted.

\section{RESULTS AND DISCUSSION}

Apterous parthenogenetic females of $S$. graminis were first collected with a yellow pan trap in Curitiba in June and July 1998, during the winter. In the spring of the same year, in September and October, the species was collected on Poaceae: Erianthus sp., Calamagrotis sp. and Paspalum urvilei, in the same area where the traps were. Large colonies were observed mainly on the inflorescence and a few specimens on the stem. Two years later, $S$. graminis was collected again on the same host plants and in the same area in the late fall, in May and June.

\section{Diagnosis \\ Sitobion graminis}

The species presents, in life, a blue-green color with black appendixes and a light wax layer on the abdomen; it is very similar in appearance to $S$. avenae, however, it has a black cauda, while in $S$. avenae the cauda is pale (Figs. 1,2).

The cleared apterous specimens have dark antennal segments except for the third segment and the distal half of processus terminalis that are clear, but this pattern can change on weakly sclerotized specimens. The third antennal segment has $0-3$ secondary rhinaria (one specimen analyzed had four rhinaria). The head, rostral segments III, IV and V are black, with the ultimate rostral segment very short and heart shaped (Figs. 3, 4 ) similar to $S$. avenae. The thorax, abdomen, siphunculi, sub-genital and sub-anal plates, cauda and legs are dark, except for the third basal part of the femur and three quarters of the tibia. The abdomen presents variable pigmentation in well sclerotized specimens (Figs. 5, 6), but in the weakly sclerotized specimens, the head, legs, siphunculi, cauda, sub-genital and sub-anal plates are black. The cauda is elongated and has 7-10 hairs.

Table I. Morphometric data (mean \pm range) of viviparous females of Sitobion graminis reared on Paspalum urvilei under laboratory conditions (average temperature $=20.7^{\circ} \mathrm{C}$ )

\begin{tabular}{lcr}
\hline Character $(\mathrm{mm})$ & Apterae $(\mathrm{n}=77)$ & Alatae $(\mathrm{n}=7)$ \\
\hline Body length & $2.05(1.53-2.46)$ & $2.22(1.82-2.53)$ \\
Hind tibia & $1.51(1.23-1.78)$ & $1.47(1.35-1.56)$ \\
Hind femur & $0.81(0.65-0.98)$ & $0.79(0.75-0.83)$ \\
Siphunculus & $0.52(0.35-0.67)$ & $0.48(0.44-0.53)$ \\
Extent of reticulation on siphunculus & $0.12(0.07-0.17)$ & $0.11(0.1-0.13)$ \\
Caudal length & $0.35(0.23-0.43)$ & $0.29(0.23-0.38)$ \\
Antennal segment III & $0.58(0.45-0.71)$ & $0.56(0.52-0.61)$ \\
Antennal segment IV & $0.42(0.31-0.56)$ & $0.43(0.32-0.49)$ \\
Antennal segment V & $0.37(0.31-0.44)$ & $0.39(0.34-0.42)$ \\
Base of antennal segment VI & $0.15(0.13-0.19)$ & $0.15(0.14-0.17)$ \\
Processus terminalis & $0.95(0.76-1.19)$ & $0.96(0.56-1.05)$ \\
Ultimate rostral segment & $0.12(0.11-0.13)$ & $0.12(0.11-0.12)$ \\
Hind tarsus segment II & $0.16(0.13-0.17)$ & $0.16(0.14-0.17)$ \\
Longest hair on antennal segment II & $0.013(0.01-0.018)$ & $0.012(0.010 .015)$ \\
Longest cephalic hair & $0.011(0.007-0.013)$ & $0.009(0.007-0.013)$ \\
\hline
\end{tabular}




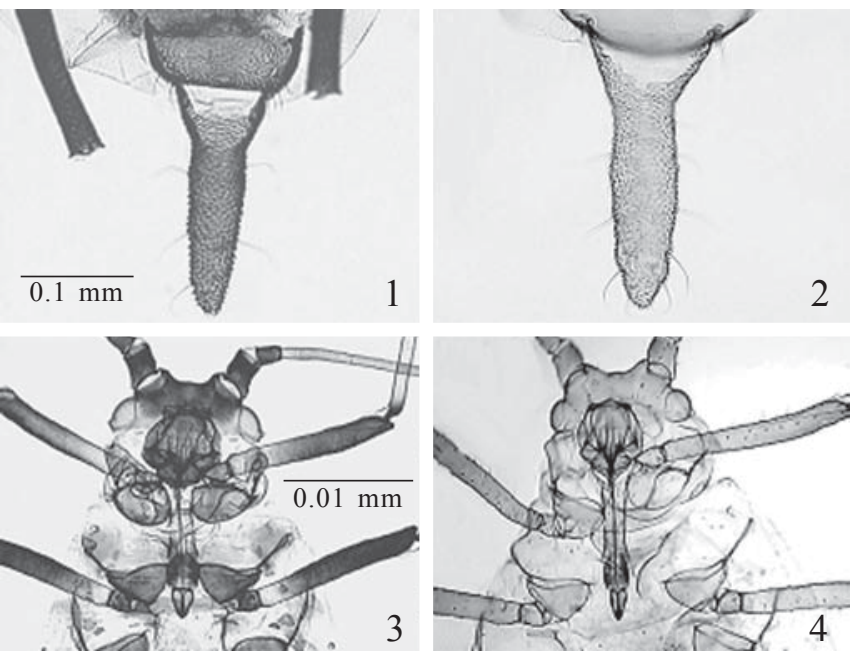

Figs. 1-4. Cauda of viviparous female of Sitobion graminis (1) and Sitobion avenae (2); Rostrum of apterous viviparous female of Sitobion graminis (3) and Sitobion avenae (4).

The alate cleared specimens are similar to the apterous specimens, but the third antennal segment generally is darker than in the apterous morph, with 1-11 secondary rhinaria. The abdominal pigmentation is less marked and the cauda has 6-9 hairs. The morphometric data show a high variability on the studied population (Table I).

\section{Sitobion avenae}

The color varies from brown to rose and green, with dark appendixes; the cauda has the same color as the body, in contrast with $S$. graminis in which it is black. The cleared apterous specimens are pale with darker femur, apex of the tibia and tarsus, while the rest of the leg is pale, agreeing with Cottier (1953), Holman (1974) and Blackman \& Eastop (1984). The cuticle presents intersegmental markings different from those of the live sclerotized S. graminis specimens (Fig. 7). The body size ranges from 1.3 to $3.3 \mathrm{~mm}$ in length. The siphunculi are from slightly dark to completely dark and the cauda is of the same color as the body, or slightly smoky. The third antennal segment has $1-5$ secondary rhinaria. The head is darker, with pale rostral segments with the ultimate segment similar in form to $S$. graminis. The cauda is elongated and has 8-18 hairs.

The alate cleared specimens are similar to the apterous, but the dorsal intersegmental markings are darker in the alate (Blackman \& Eastop 1984). The body length varies between 1.6 and $2.9 \mathrm{~mm}$ in length, the antenal segment III has $8-16$ secondary rhinaria and the cauda has 7-10 hairs (Cottier 1953 and Blackman \& Eastop 1984).

\section{Biology}

The mean temperature during the tests was $20.7^{\circ} \mathrm{C}$ (minimum of $16.9^{\circ} \mathrm{C}$ and maximum of $24.4^{\circ} \mathrm{C}$ ). Of the 30 nymphs initially isolated, a total of 19 parthenogenetic females were obtained, of which 16 were apterae and only 3 were winged. According to Kawada (1987) and Miyazaki (1987), the variation between the morphs is determined genetically, selected by environmental factors such as low temperatures, photophase and overpopulation. The apterous forms are responsible for colonizing the plant, while the winged forms are produced when the population is very high and are responsible for migration, which would explain why in laboratory tests few winged females are found.

Four nymphal instars were recorded with a mean of 11.4 days for the duration of the total stage (Table II); the $1^{\text {st }}$ instar had the longest and the $3^{\text {rd }}$ instar the shortest duration period. The total mortality of the nymphal stage was $36.5 \%$ (Table II); the highest mortality occurred in the $3^{\text {rd }}$ instar.

The mean pre-larviposition period was 1.8 days. The average life cycle was 25.6 days, displaying great variation $(\mathrm{DP}=6.1)$ ranging from 14 to 38 days. The mean fecundity was 18.7 nymphs/female, ranging from 2 to 41 .

According to Victor Eastop (personal comm.), the morphological variability observed inside a given population of S. graminis has been verified not only in Brazil, but also in the African continent. He mentions that in order to appreciate the intrapopulation variability, more accurate studies are needed, including molecular analysis and the effect of temperature and photoperiod on the production of polymorphism.

The distribution of $S$. graminis in Brazil should also be determined, as well as the potential of this species for damaging gramineae of economic importance, since the species presents

Table II. Biological data of alate viviparous females of Sitobion graminis reared on Paspalum urvilei under laboratory conditions (average temperature $=20.7^{\circ} \mathrm{C}$ ).

\begin{tabular}{lcr}
\hline Parameters & Average (SD) [range] & Mortality (\%) \\
\hline $1^{\text {st }}$ Instar (days) & $4.7(0.7)[4-6]$ & 13.3 \\
$2^{\text {nd }}$ Instar (days) & $2.1(1.1)[1-6]$ & 03.3 \\
$3^{\text {rd }}$ Instar (days) & $1.9(0.8)[1-4]$ & 16.6 \\
$4^{\text {rd }}$ Instar (days) & $2.8(0.8)[2-4]$ & 03.3 \\
Pre-larviposition period (days) & $1.8(1.1)[1-4]$ & - \\
Adult (days) & $12.3(4.9)[2-25]$ & - \\
Daily Fecundity (nymphs/day) & $1.4(0.6)[2-41]$ & - \\
Total fecundity (nymphs/female) & $18.7(11.4)[0.4-2.45]$ & - \\
\hline
\end{tabular}




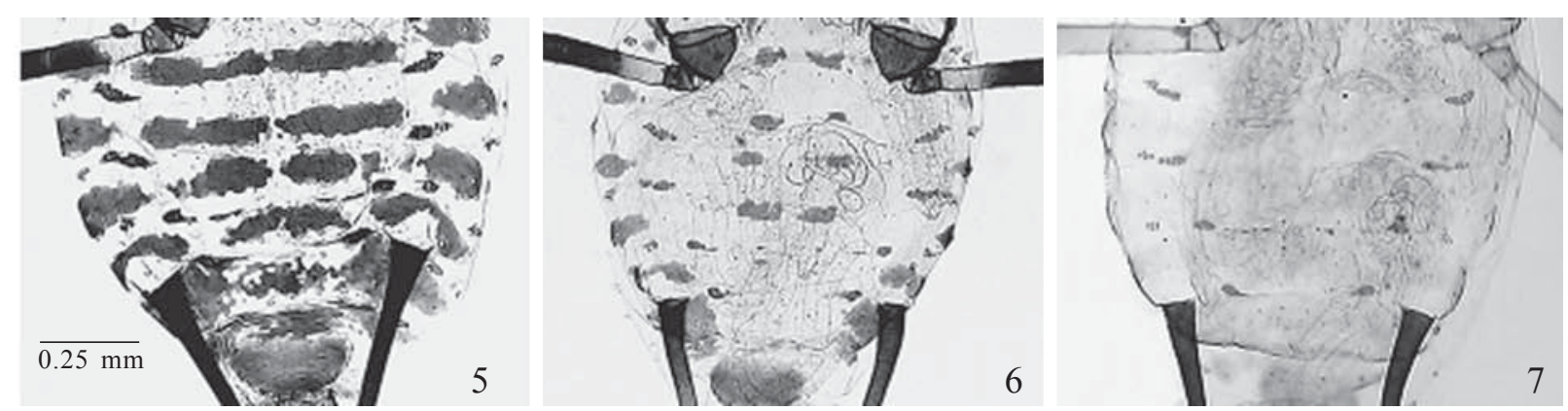

Figs. 5-7. Abdomen of apterous viviparous female Sitobion graminis (5 and 6); Sitobion avenae (7).

high fecundity. The correct identification of this grass feeding species in the field deserves attention due to its similarity with S. avenae.

Acknowledgments. We are grateful to Dr. V.F. Eastop, from the Natural History Museum, London for the identification and comments about the aphid species. The first two authors were supported by fellowships from CNPq.

\section{REFERENCES}

Blackman, R. L. \& V. F. Eastop. 1984. Aphids on the world's crop: an identification and information guide, London, John \& Sons, $465 \mathrm{p}$.

Costa, L. C.; V. F. Eastop \& R. L. Blackman. 1993. Brazilian Aphidoidea: II. Accounts of the Lachninae, Chaitophorinae, Greenideinae, Anoeciinae and Hormaphidinae. Pesquisa Agropecuária Brasileira, 3: 269-280.

Cottier, W. 1953. Aphids of the New Zealand. Wellington, Department of Scientific and Industrial Research, $382 \mathrm{p}$.

Eastop, V. F. 1955. New east African aphids (Hem., Aphididae). Entomologists Monthly Magazine 91: 154-160.
Holman, J. 1974. Los áfidos de Cuba. Havana, Editorial Organismos, $304 \mathrm{p}$.

Kawada, K. 1987. Polymorphism and morph determination, Vol. 2A, 255-268. In: Minks, A. K. \& P. Harrewijn (Eds.). World crop pests: Aphids, their biology, natural enemies and control. Amsterdam, Elsevier Science Publishers, 364 p.

Martin, J. H. 1983. The identification of common aphid pest of tropical agriculture. Tropical Pest Management 29: 395-411.

Miyazaki, M. 1987. Forms and morphs of aphids, Vol. 2A, 27-50. In. Minks, A. K. \& P. Harrewijn (Eds.). World crop pests: Aphids, their biology, natural enemies and control. Amsterdam, Elsevier Science Publishers, 364 p.

Remaudière, G. \& A. Autrique. 1985. Ecologie des aphides du Burundi, p. 11-75. In: Remaudiére, G. (Ed.). Contribution à l'écologie des aphides africains. Rome, Organisation des Nations Unies pour L'alimentation et L'agriculture, $214 \mathrm{p}$.

Remaudière, G.; G. Aymonin \& A. Autrique. 1985. Les plantes hotes des pucerons africains, p. 103-140. In: Remaudiére, G. (Ed.). Contribution à l'écologie des aphides africains. Rome, Organisation des Nations Unies pour L'alimentation et L'agriculture, $214 \mathrm{p}$.

Takahashi R. 1950. List of the Aphididae of the Malay Peninsula, with descriptions of new species (Homoptera). Annals of Entomological Society of America 43: 587-560.

Voegtlin, D.; W. Villalobos; M. V. Sánchez; G. Saborio \& C. Rivera. 2003. A guide to the winged aphids of Costa Rica (Guía de los áfidos alados de Costa Rica). Revista de Biología Tropical 51: 1-214. 